\title{
ASSESSMENT OF ACCOUNTING LIQUIDITY AND WORKING CAPITAL MANAGEMENT STRATEGIES OF FUSING COMPANIES WITHIN THE PERIOD OF ECONOMIC CRISIS BETWEEN 2008 - 2011
}

\author{
Piotr Luty \\ Finance department, Wrocław University of Economics, Wrocław, Poland
}

\begin{abstract}
:
Business combinations are a popular strategy for companies expansion. In the modern world, the strategic expansion is not limited by territories of the countries, which leads to cross-border mergers. The share of domestic mergers (companies within one country) is much larger than the cross-border mergers. This paper puts an emphasis on mergers of Polish companies (domestic mergers), which took place in the period of economic slowdown in the years $2008-2011$.

This paper assesses different factors influencing the liquidity of merging companies. Herein, I examine liquidity factors of potential acquirers and target companies, compared to an average Polish company, as well as the impact of working capital management strategy on the cash conversion cycle.
\end{abstract}

\author{
Key words: \\ mergers and acquisitions, \\ liquidity ratios, \\ financial position.
}

\section{INTRODUCTION}

Mergers of economic units are an indispensable element of development of the companies [6]. In the contemporary world of economics, development of companies is not limited by the territories of the states, which leads to creation of trans-border mergers [7]. Percentage of merger processes within one country is much larger than it is in case of trans-border mergers. The herein article focuses on merger processes related to the companies seated in Poland. The time frame of the study covers the period of economic crisis between 2008 and 2011.

The basic aim of the article is to assess the financial liquidity of companies which plan to be involved in a merger (companies which are overtaking and companies which are being overtaken), as well as the impact of management of the working capital on financial liquidity measured with a money conversion cycle. The Polish literature on the subject states that financial liquidity can be described in two dimensions: asset and asset-equity. Liquidity in the aspect of assets means that the assets have a capacity of being replaced with money in the shortest amount of time possible, without losing their value" [1]. Liquidity within the assets-equity aspect is related to the mutual relation of liabilities which fund the assets and asset which is treated as a security measure, which secures due payment of these liabilities.

The Polish literature indicates that the analysis of financial liquidity of economic subjects shall consist of three founding elements: property collateral, income collateral and liquidity profile. The first founding element is the analysis of the property collateral in a liquidation dimension. This analysis needs to answer the question: how much of the assets need to be liquidated in order to pay the ongoing liabilities in a longer, moderate and shorter amounts of time [2]. The latter foundation is based on the analysis of cash sources and ways of disbursing the money. Within that foundation, the following answers are looked for: what sources of cash are available and how it has been spent (character analysis), is the operational cash enough to pay the ongoing liabilities (indicator of covering the ongoing liabilities with the cash flow) and is the available money going to secure the fluctuation of the flow (lambda liquidity indicator) [2]. The third founding block of the liquidity, in other words - it is related to looking at the causes for given level of the financial liquidity. Within that research area, indicator of contribution of the working capital in assets, cash conversion cycle and working capital cycle [2]. Relationship between working assets and short terms liability is a factor which determines the working capital management strategy applied by the company - in a way which is conscious or not. In a classic division - three strategies of managing the working capital can be distinguished. The aggressive strategy assumes that ongoing liabilities are of bigger value than the current assets. The conservative strategy is characterized by the fact that the current assets are at higher level than the ongoing liabilities, which provides a kind of buffer for the company, which would come in handy, when possible payment problems may occur.

The article is based on four research hypotheses:

H1: Companies which plan a merger (acquirer companies) have an above-average level of financial liquidity.

$\mathrm{H} 2$ : Companies which plan a merger (target companies) have a below-average level of financial liquidity.

H3: Strategy of management regarding the working capital has an impact on financial liquidity of companies which are planning a merger (acquirer companies).

H4: Strategy of management regarding the working capital has an impact on financial liquidity of companies which are planning a merger (target companies).

\section{METHODOLOGY AND SELECTION OF A RESEARCH SAMPLE}

Financial data of the merging companies come from the Lex Omega database. "Due to the fact that the companies within that base cannot be filtered for overtaking and overtaken companies, a filter has been established to find published entries in the National Court Registry, which are characterized by keywords: "merging plan" and "merger".

Another criterion in further selection of merging companies was the availability of the financial statements of both overtaking and overtaken companies. The study focused solely on Limited companies. In the Polish conditions, Limited Companies (limit- 
ed liability companies and joint stock companies) have to submit the annual financial statements to the competent Registry Court at the end of the FY. When it comes to joint-stock companies and other subjects that are a subject of audit (Accounting Act, 2013, Article 64, section 1), additional requirement has been created - these companies need to publish their financial statements in official gazette: "Court and Economic Monitor" (Accounting Act, 2013, Article 70, sec. 2). Obligation of publication of the financial statements in the official gazettes contributed to easier access to the financial data, which concerned the merging companies (only in several cases the financial statements of joint-stock companies were missing). Problems related to the information access was present in case of the limited liability companies. These companies either did not submit financial statements (such conclusion has been formulated on the basis of lack of note within the characteristics of the company in the submitted statement - Lex Omega Database), and if the statements have been filed in the National Court Registry, they were not available in an electronic form (access is possible only in case of a printed form, available in the files reading room of the registry court). In such case, the tested sample has been additionally filtered within the scope of the joint-stock companies. The analysis excluded the companies of the National Treasury and banks and financial companies, as well as energy industry companies." [3].

The acquirer and target companies, which have merged in the period between 2008 - 2011, have been selected. Empirical material collected is not full due to the fact that neither did some companies publish their financial statements, nor were the statements available in the database in an electronic form. The examination of the existing statements may not have been completed.

On the basis of the collected financial data of the companies which are being merged, 121 financial statements of the companies have been received, in case of which the statement has been created 1 year before the merging process, 127 statements for the period 2 years before the merger and 73 financial statements of the companies 3 years before the merger.

The analysis of the acquirer and target companies includes 66 financial statements of the acquirer companies regarding the period 1 year before the merger, 67 financial statements of acquirer companies for the period 2 years before merger and finally, 33 financial statements of the acquirer companies for the period 3 years before the merger.

The analysis of the acquirer and target companies includes 55 financial statements of the target companies regarding the period 1 year before the merger, 60 financial statements of target companies for the period 2 years before merger and finally, 40 financial statements of the target companies for the period 3 years before the merger.

Within the period of financial crisis (2008 - 2011) the analysis of the following material has been carried out: 90 statements in 2008, 102 statements in 2009, 82 statements in 2010 and 22 statements in 2011.

In order to verify the $\mathrm{H} 1$ and $\mathrm{H} 2$ hypotheses, liquidity indicators and components of the cash conversion cycle has been analyzed (inventory conversion cycle, liabilities payment period and period dues payment period). Structure of the indicators is following:

$$
\begin{gathered}
\text { indicator of the current liquidity }=\frac{\text { value of the current assets }}{\text { short term liabilities }} \\
\text { indicator of the quick liquidity }=\frac{\text { short term receivables }+ \text { short term investments }}{\text { short term liabilities }} \\
\text { indicator of the cash liquidity }=\frac{\text { short term investments }}{\text { short term liabilities }}
\end{gathered}
$$

Cash conversion cycle is calculated in accordance with the methodology accepted by the Financial Analysis Commission of the Accountants Association. The instructions for the cash conversion cycle (indicated by CCC abbreviation in the formula) is following:

$$
\mathrm{CCC}=\mathrm{OSN}+\mathrm{CKZ}-\mathrm{OSZ}
$$

Period of liability payment (abbr. OSN) has the following formula:

$$
\text { OSN }=\frac{365^{*} \text { Short period receivables }}{\text { Sales }}
$$

Inventory conversion period has a formula as follows (abbr. CKZ):

$$
\mathrm{CKZ}=\frac{365^{\star} \text { Inventory }}{\text { Sales }}
$$

Liability payment period (OSZ) is calculated in accordance with the following formula:

$$
\text { OSZ }=\frac{365 * \text { Short term liabilities }}{\text { Sales }}
$$

Verification of $\mathrm{H} 1$ and $\mathrm{H} 2$ hypotheses will be realized through a single-sided test of the hypothesis about an average value in the population. Average value of the liquidity indicators regarding the companies which undergo merging (overtaking and overtaken ones) will be compared with an average value of these indicators calculated for all the companies in Poland (data comes from the studies of the Financial Analysis Commission of the Polish Accountants Association).

One-sided test statistics are going to take " $\mathrm{z}$ " statistic into account. This value has been described by D. Aczel, and it has the following format:

$$
\begin{gathered}
\mathrm{z}=\frac{365{ }^{\star} \text { Short period receivables }}{\text { Sales }} \\
\mathrm{z}=\frac{\overline{\mathrm{x}}-\mu}{\mathrm{s} / \sqrt{\mathrm{n}}}
\end{gathered}
$$

where:

$\mu$-average in population; $\mathrm{x}$ - average in the test;

s-standard deviation; n-quantity.

When it comes to right-sided test, in cases when " $\mathrm{z}$ " statistics value is higher than the critical point for the defined level of relevance, a decision shall be considered to reject the zero hypothesis. In case of using a left-sided test, when " $z$ " statistics value is lower than the critical point for the defined level of relevance, one should decide on rejection of the zero hypothesis.

Verification of $\mathrm{H} 3$ and H4 Hypotheses is based on an assumption, according to which the strategy of the working capital (difference between the current assets and ongoing liabilities or difference between fixed capital and fixed assets), may be described with an ongoing liquidity indicator, hereinafter referred to as WC. Structure of the WC indicator is as follows:

$$
\mathrm{WC}=\frac{\text { value of the current assets }}{\text { short term liailities }}
$$

On the basis of the research carried out by M. Bolek [5] within the Polish stock exchange, the following strategies of managing the working capital have been defined:

$$
\begin{array}{ll}
\mathrm{WC}<1 & \text { - aggressive strategy } \\
1<\mathrm{WC}<2 & \text { - moderate strategy } \\
\mathrm{WC}>2 & \text { - conservative strategy }
\end{array}
$$

Verification of $\mathrm{H} 3$ and $\mathrm{H} 4$ hypotheses will be based on checking whether in the merging companies a linear correlation between the working capital management strategy and cash conversion cycle exists. 


\section{RESULTS}

Verification of the H1 hypothesis, which describes aboveaverage liquidity indicators of the acquirer companies requires formulation of $0\left(\mathrm{H}_{0}\right)$ and alternative $\left(\mathrm{H}_{1}\right)$ hypotheses, which will be tested against the " $\mathrm{z}$ " statistics, for a level of relevance equal to 0.01 .

$\mathrm{H}_{0}$ : average values of the liquidity indicators for companies which are acquirer are higher or equal than the average liquidity indicators of the Polish companies.

$\mathrm{H}_{1}$ : average values of the liquidity indicators for companies which are acquirer are lower than the average liquidity indicators of the Polish companies.

Critical value for " $\mathrm{z}$ " statistics for the 0.01 relevance level is -2.326 .

Values of the average liquidity indicators (indicators of current, quick and cash liquidity), as well as " $\mathrm{z}$ " statistics and undertaken test decisions for the 0 and alternative hypotheses are all presented in table 1, 2 and 3 .

\begin{tabular}{ccccc}
\hline Year & $\begin{array}{c}\text { Population } \\
\text { average } \\
\text { value }\end{array}$ & $\begin{array}{c}\text { average } \\
\text { value in the } \\
\text { test }\end{array}$ & "z" statistic & decision \\
\hline 2008 & 2.24 & 1.86 & -1.74 & H0 \\
\hline 2009 & 2.24 & 1.71 & -3.32 & H1 \\
\hline 2010 & 2.22 & 1.51 & -4.27 & H1 \\
\hline 2011 & 2.21 & 1.04 & -3.4 & H1 \\
\hline
\end{tabular}

Table 1: Current liquidity indicator

\begin{tabular}{ccccc}
\hline Year & $\begin{array}{c}\text { Population } \\
\text { average } \\
\text { value }\end{array}$ & $\begin{array}{c}\text { average } \\
\text { value in the } \\
\text { test }\end{array}$ & "z" statistic & decision \\
\hline 2008 & 1.63 & 1.13 & -3.83 & H1 \\
\hline 2009 & 1.6 & 1.19 & -3.26 & H1 \\
\hline 2010 & 1.61 & 1.02 & -4.77 & H1 \\
\hline 2011 & 1.61 & 0.68 & -4.39 & H1 \\
\hline
\end{tabular}

Table 2: Quick liquidity indicators

\begin{tabular}{ccccc}
\hline Year & $\begin{array}{c}\text { Population } \\
\text { average } \\
\text { value }\end{array}$ & $\begin{array}{c}\text { average } \\
\text { value in the } \\
\text { test }\end{array}$ & "z" statistic & decision \\
\hline 2008 & 0.62 & 0.27 & -6.08 & H1 \\
\hline 2009 & 0.62 & 0.32 & -4.18 & H1 \\
\hline 2010 & 0.62 & 0.24 & -6.54 & H1 \\
\hline 2011 & 0.61 & 0.05 & -34.34 & H1 \\
\hline
\end{tabular}

Table 3: Cash liquidity indicator

On the basis of the statistical test an alternative $\mathrm{H}_{1}$ hypothesis needs to be assumed, which states that the average liquidity indicators of the overtaking companies within the period 2008 - 2011 have been lower than the average values for an average Polish company.

Verification of the $\mathrm{H} 2$ hypothesis, which describes worse liquidity indicators of the target companies in relation to the remaining companies, requires formulation of $0\left(\mathrm{H}_{0}\right)$ and alternative $\left(\mathrm{H}_{1}\right)$ hypotheses, which will be tested against the " $\mathrm{z}$ " statistics, for a level of relevance equal to 0.01 .

$\mathrm{H}_{0}$ : average values of the liquidity indicators for companies which are target companies are lower than or equal to the average liquidity indicators of the Polish companies.

$\mathrm{H}_{1}$ : average values of the liquidity indicators for companies which are target companies are higher than the average liquidity indicators of the Polish companies.

Critical value for " $\mathrm{z}$ " statistics for the 0.01 relevance level is +2.326 .

Values of the average liquidity indicators (indicator of current, quick and cash liquidity), as well as " $\mathrm{z}$ " statistics and un- dertaken test decisions for the hypotheses ( 0 and alternative) are all presented in table 4, 5 and 6 .

\begin{tabular}{ccccc}
\hline year & $\begin{array}{c}\text { Population } \\
\text { average } \\
\text { value }\end{array}$ & $\begin{array}{c}\text { average } \\
\text { value in the } \\
\text { test }\end{array}$ & "z" statistic & decision \\
\hline 2008 & 2.24 & 1.7 & -2.75 & H0 \\
\hline 2009 & 2.24 & 2.59 & 0.85 & H0 \\
\hline 2010 & 2.22 & 2.72 & 0.89 & H0 \\
\hline 2011 & 2.21 & 1.81 & -0.73 & H0 \\
\hline
\end{tabular}

Table 4: Current liquidity indicator

\begin{tabular}{ccccc}
\hline year & $\begin{array}{c}\text { Population } \\
\text { average } \\
\text { value }\end{array}$ & $\begin{array}{c}\text { average } \\
\text { value in the } \\
\text { test }\end{array}$ & "z" statistic & decision \\
\hline 2008 & 1.63 & 1.2 & -3.25 & H0 \\
\hline 2009 & 1.6 & 2 & 1.07 & H0 \\
\hline 2010 & 1.61 & 2.13 & 1.03 & H0 \\
\hline 2011 & 1.61 & 1.36 & -0.46 & H0 \\
\hline
\end{tabular}

Table 5: Quick liquidity indicators

\begin{tabular}{ccccc}
\hline year & $\begin{array}{c}\text { Population } \\
\text { average } \\
\text { value }\end{array}$ & $\begin{array}{c}\text { average } \\
\text { value in the } \\
\text { test }\end{array}$ & "z" statistic & decision \\
\hline 2008 & 0.62 & 0.27 & -6.29 & H0 \\
\hline 2009 & 0.62 & 0.58 & -0.28 & H0 \\
\hline 2010 & 0.62 & 0.5 & -0.78 & H0 \\
\hline 2011 & 0.61 & 0.3 & -1.46 & H0 \\
\hline
\end{tabular}

Table 6: Cash liquidity indicator

There is no argument for rejecting the zero hypothesis, $\mathrm{H}_{0}$, on the basis of the statistical test. This hypothesis claims that average values of liquidity indicators regarding the target companies within the period between 2008 and 2011 had been lower or equal to the average values for average Polish companies.

Verification of the $\mathrm{H} 3$ and $\mathrm{H} 4$ hypotheses, which claim that the strategy of management regarding the working capital has an impact on financial liquidity of the acquirer and target companies, has been carried out by defining the correlation coefficient, which describes the strategy of managing the working capital WC (WC is equal to current liquidity indicator) and cash conversion cycle. Defining the strategy of working capital management has been defined on the basis of the research conducted by M. Bolek.

Correlation factors for the acquirer companies are presented in tables 7, 8 and 9 .

\begin{tabular}{ccccc}
\hline & WC & CCC & $\begin{array}{c}\text { average } \\
\text { value }\end{array}$ & $\begin{array}{c}\text { standard } \\
\text { deviation }\end{array}$ \\
\hline WC & 1.000000 & 0.003484 & 0.6114 & 0.24280 \\
\hline CCC & 0.003484 & 1.000000 & -20.8148 & 16.79294 \\
\hline
\end{tabular}

Table 7: Aggressive strategy

\begin{tabular}{ccccc}
\hline WC & CCC & $\begin{array}{c}\text { average } \\
\text { value }\end{array}$ & $\begin{array}{c}\text { standard } \\
\text { deviation }\end{array}$ \\
\hline WC & 1.000000 & -0.248359 & 1.4947 & 0.27580 \\
\hline CCC & -0.248359 & 1.000000 & -29.3778 & 14.00047 \\
\hline
\end{tabular}

Table 8: Moderate strategy

\begin{tabular}{ccccc}
\hline WC & CCC & $\begin{array}{c}\text { average } \\
\text { value }\end{array}$ & $\begin{array}{c}\text { standard } \\
\text { deviation }\end{array}$ \\
\hline WC & 1.000000 & 0.401016 & 3.2007 & 0.89761 \\
\hline CCC & 0.401016 & 1.000000 & -28.8537 & 76.51031 \\
\hline
\end{tabular}

Table 9: Conservative strategy 
Additionally a weak negative relationship between the moderate strategy of capital management and cash conversion cycle is noted. Additionally a weak positive relationship between the conservative strategy of capital management and cash conversion cycle is noted.

Correlation factors for the overtaken companies are presented in tables 10, 11 and 12:

\begin{tabular}{ccccc}
\hline & WC & CCC & $\begin{array}{c}\text { average } \\
\text { value }\end{array}$ & $\begin{array}{c}\text { standard } \\
\text { deviation }\end{array}$ \\
\hline WC & 1.000000 & -0.479689 & 0.7476 & 0.192407 \\
\hline CCC & -0.479689 & 1.000000 & -10.7872 & 7.258986 \\
\hline
\end{tabular}

Table 10: Aggressive strategy

\begin{tabular}{rrrcc}
\hline & WC & CCC & $\begin{array}{c}\text { average } \\
\text { value }\end{array}$ & $\begin{array}{c}\text { standard } \\
\text { deviation }\end{array}$ \\
\hline WC & 1.000000 & 0.011706 & 1.40235 & 0.282718 \\
\hline CCC & 0.011706 & 1.000000 & -8.57143 & 7.802885 \\
\hline
\end{tabular}

Table 11: Moderate strategy

\begin{tabular}{rcccc}
\hline & WC & CCC & $\begin{array}{c}\text { average } \\
\text { value }\end{array}$ & $\begin{array}{c}\text { standard } \\
\text { deviation }\end{array}$ \\
\hline WC & 1.000000 & 0.663373 & 4.948266 & 3.1546 \\
\hline CCC & 0.663373 & 1.000000 & 0.285714 & 110.2488 \\
\hline
\end{tabular}

Table 12: Conservative strategy

Correlation analysis makes it possible to conclude that in case of the target companies an average negative relationship is present between the aggressive management strategy, when it comes to the working capital, and the cash conversion cycle. Additionally an average positive relationship between the conservative strategy of capital management and cash conversion cycle is noted.

\section{CONCLUSION}

The logic of merger processes between the economic subjects may lead us to a statement that better companies (acquirer companies) shall overtake the worse companies (target companies). Test results make it possible to conclude that during the economic crisis in Poland, within the period between 2008 and 2011, the acquirer companies did not have above-average indicators of financial liquidity. However, conjecture (contained in the $\mathrm{H}_{2}$ ) hypothesis, that the target companies have worse results that average companies on the Polish market, is confirmed.
Research within the scope of financial condition of the merging companies will be continued by the Author in his future research. It shall be noted that the results of the research may be under influence of the selected period of the economic crisis, and various values describing the companies adapting to the variable economic environment. Additionally average population data has been analyzed instead of sector data.

In case of the analysis of the impact of the assumed working capital management strategy on the cash conversion cycle, no unequivocal verification of the stated $\left(\mathrm{H}_{3}, \mathrm{H}_{4}\right)$ research hypotheses is possible. Depending on strategies used to manage the working capital (aggressive, moderate or conservative), positive, negative or no dependence were noted in target or acquirer companies.

\section{REFERENCES}

[1] D. Wędzki, Strategie płynności finansowej przedsiębiorstwa. [Strategies of financial liquidity for a Business] Przepływy pieniężne a wartość dla właścicieli, [Cash flow and its value for the owners], Oficyna Ekonomiczna, Kraków, 2003

[2] D. Wędzki, Analiza wskaźnikowa sprawozdani finansowego, Tom 2. [Indicator Analysis of Financial Statement, Vol. 2] Wskaźniki finansowe, [Financial Indicators] Wolters Kluwer Polska sp z o.o., Kraków, 2009

[3] P. Luty, Ocena kondycji finansowej łączacych się spółek na przykładzie jednostek $z$ wybranych województw Polski Zachodniej, [Assessment of Financial Condition of Merging Companies on the basis of Businesses from Selected Voivodeships of the Western Poland] Zeszyty Teoretyczne Rachunkowości tom 75 (131), Stowarzyszenie Księgowych w Polsce, Warszawa, 2014

[4] A.D. Aczel, Statystyka w zarzadzaniu, [Statistics in Management] Wydawnictwo Naukowe PWN, Warszawa, 2000

[5] M. Bolek, R. Pastusiak, Wpływ strategii zarzadzania kapitałem pracujacym na płynność przedsiębiorstwa na przykładzie spółek notowanych na GPW w Warszawie [Impact of Working Capital Management Strategy on Liquidity of a Business on the Basis of Companies Present within the Warsaw Stock Exchange], Zeszyty Naukowe Uniwersytetu Szczecińskiego nr 803, Szczecin, 2014

[6] K.Shimizu, M.A. Hitt, D. Vaidyanath, V. Pisano, Theoretical foundations of cross-border mergers and acquisitions: A review of current research and recommendations for the future, Journal of International Management 10/2004, pp. 307-353

[7] Makaew T., The Dynamics of International Mergers and Acquisitions, working papers http://papers.ssrn.com/sol3/ papers.cfm?abstract_id=1572005

\title{
PROCENA RAČUNOVODSTVNE LIKVIDNOSTI I UPRAVLJANJE OBRTNIM SREDSTVIMA PREDUZEĆA U PERIODU EKONOMSKE KRIZE IZMEĐU 2008. - 2011.
}

\author{
Piotr Luty
}

Finances department, Wrocław University of Economics, Komandorska 118-120, 53-345 Wrocław, Poland, piotr.luty@ue.wroc.pl

\section{Apstrakt:}

Poslovne kombinacije predstavljaju popularnu strategiju za širenje kompanija. U savremenom svetu, strateško širenje nije teritorijalno organičeno granicama zemlje, što vodi do prekograničnih spajanja. Udeo domaćih spajanja (preduzeća u okviru iste države) je dosta veći od prekograničnih spajanja. Ovaj rad stavlja naglasak na spajanje kompanija u Poljskoj (unutar jedne države), u periodu ekonomske krize (2008-2011). U njemu se analiziraju različiti činioci koji utiču na likvidnost datih preduzeća. Naime, ispituju se faktori likvidnosti potencijalnih preduzeća kupaca i ciljanih preduzeća u odnosu na prosečnu kompaniju u Poljskoj, kao i uticaj strategije upravljanja obrtnim kapitalom na operativni ciklus gotovine.
}

\section{Ključne reči:}

merdzeri (spajanja) i akvizicije, pokazatelji likvidnosti, finansijski položaj. 